\title{
Assessing the Quality of Clinical Practice Guidelines in the Middle East and North Africa (MENA) Region: A Systematic Review
}

This article was published in the following Dove Press journal: Journal of Multidisciplinary Healthcare

\author{
Saja H Almazrou (D' \\ Layan A Alsubki' \\ Norah A Alsaigh' \\ Wadha H Aldhubaib' \\ Sharifah M Ghazwani ${ }^{2}$ \\ 'Clinical Pharmacy Department, College \\ of Pharmacy, King Saud University, \\ Riyadh, Saudi Arabia; ${ }^{2}$ College of \\ Pharmacy, Jazan University, Jazan, Saudi \\ Arabia
}

\begin{abstract}
Aim: Clinical practice guidelines (CPGs) have progressively become a popular tool for making optimal clinical decisions. The literature shows that the poor quality of CPGs can form a barrier against adhering to them, resulting in a suboptimal level of healthcare. The objective of this systematic review is to evaluate the quality of CPGs in the Middle East and North Africa (MENA) region using the Appraisal of Guidelines for Research \& Evaluation II (AGREE II) Instrument.

Methods: The authors searched in the MEDLINE and EMBASE databases through the Ovid interface on May 25, 2019. Keywords relating to CPGs and MENA countries were combined using Boolean search operators. The search was not limited to specific diseases. The quality of guidelines was appraised by two reviewers independently using the AGREE II Instrument. Discrepancies within a group were resolved through the involvement of a principle investigator.

Results: A total of 61 CPGs were appraised. These guidelines were mainly from Saudi Arabia, and the most covered disease topic was cancer. Among the six domains of the AGREE II Instrument, CPGs scored the highest on clarity of presentation (mean 82\%), while the lowest score was granted to the rigor of development domain (mean 28\%). This indicates substantial deficiencies in reporting the developmental processes of CPGs and the resources used for the synthesis of evidence.

Conclusion: From this review, it was found that the number of retrieved guidelines published in the MENA region is limited considering the large geographical area of the MENA region. The main domains that have higher quality scores were clarity of presentation and scope and purpose, whereas domains with the lowest scores were rigor of development and applicability. The authors' findings will help policymakers identify areas for improvement in CPGs, which can lead them to implement strategies such as the training of individuals and recruitment of international experts to ultimately develop high-quality CPGs.
\end{abstract}

Keywords: AGREE II Instrument, clinical practice guideline, MENA, Middle East, quality

\section{Background}

Clinical practice guidelines (CPGs) are defined by the Institute of Medicine (IOM) as statements that include recommendations intended to optimize patient care that are informed by a systematic review of evidence and an assessment of the benefits and harms of alternative care options. ${ }^{1}$ CPGs can provide several benefits to clinicians, institutions, and patients. The use of recommendations from CPGs assists clinicians in making decisions about individual patient management. ${ }^{2}$ On
Correspondence: Saja H Almazrou Clinical Pharmacy Department, College of Pharmacy, King Saud University, Riyadh, I45II, Saudi Arabia

Email Salmazrou@ksu.edu.sa 
an institutional level, the use of CPGs allows the provision of standardized care to patients with the aim of decreasing variations in clinical practice. ${ }^{3}$ They also improve the quality of care and reduce preventable errors in medication. ${ }^{3}$ These possible benefits can eventually promote cost-effective care. ${ }^{4}$ Also, patients can benefit from some CPGs that are accompanied by "consumer" versions, which include a simple summary of the benefits and harms of available options. ${ }^{5}$ Thus, it empowers patients to make more informed healthcare choices and to consider their personal needs and preferences in selecting the best option. $^{5}$ Nowadays, the number of published CPGs is progressively expanding. ${ }^{6}$ However, the quality of those guidelines is still inconclusive. $^{7-9}$

The AGREE II Instrument (Appraisal of Guidelines for Research \& Evaluation II) is one of the widely used, validated tools for evaluating CPGs. The instrument includes specific assessment questions that cover many aspects of the quality of guidelines with a focus on methodological rigor. ${ }^{10}$ It has been widely used to assess guidelines in various clinical conditions. ${ }^{11-16}$ High-quality clinical practice guidelines could have substantial positive impact on patients and healthcare providers. Evidence suggests that high quality could improve patients' clinical outcomes, provide an equitable clinical recommendation that are effective, safe and appropriate to the target population. ${ }^{17,18}$

To our knowledge, there is no study that reviews the quality of published guidelines for clinical practice in the Middle East and North Africa (MENA) region. Several systematic reviews have been conducted to compare the quality of guidelines among high-income countries including the United states ${ }^{19-21}$ and Europe. ${ }^{22-26}$ Similar systematic reviews were also performed for low- and middle-income countries including Turkey, ${ }^{7}$ China, ${ }^{9}$ and Sri Lanka. ${ }^{8}$ The quality of clinical practice guidelines varies across countries. In the United States and Europe, lowest scores were assigned to "applicability" and "editorial independence", whereas, in other developing countries including Turkey, China and Sri Lanka, the rigour of development received low scores on AGREE II Instrument.

The MENA region consists of high-, middle-, and lowincome countries. ${ }^{27,28}$ In addition, there are variations in the financing of healthcare and the socioeconomic contexts in these countries. ${ }^{29}$ Therefore, conclusions from the previously mentioned systematic reviews cannot be generalized to the MENA region. The aim of this study is to assess the quality of CPGs in the MENA region using the validated AGREE II Instrument. ${ }^{10}$

\section{Methodology}

The review's protocol is registered with the International Prospective Register of Systematic Reviews (PROSPERO; registration number: CRD42019132437).

\section{Identification of Guidelines}

The sources were the MEDLINE and EMBASE databases through the Ovid interface, and the review was conducted on May 25, 2019, to identify CPGs. Additionally, gray literature has been manually searched to identify CPGs in all relevant health organization websites including those of the ministries of health and medical organizations of the MENA countries involved (Appendix 1). Keywords and terms relating to CPGs and all the MENA countries were combined using Boolean search operators (Appendix 2).

\section{Selection of Guidelines}

We used the institution of medicine (IOM) definition for clinical practice guidelines:

Statements that include recommendations intended to optimize patient care that are informed by a systematic review of evidence and an assessment of the benefits and harms of alternative care options. ${ }^{1}$

Therefore, the included guidelines should fulfil the following criteria:

1. Guidelines are developed by medical societies or governmental institutions.

2. Guidelines should describe the methods used to search the literature and identify eligible studies.

3. Guidelines should provide structured recommendations based on reviewed studies.

We included English language guidelines that were produced by countries with MENA region organizations. ${ }^{27,28}$ Short summaries, narrative and systematic reviews, abstracts, and posters were excluded. The detailed criteria are listed in Table 1.

\section{Data Collection Process}

One author (N. A.) conducted the search of electronic databases. Three authors-L. S., N. A., and W. H.searched and screened the gray literature. Afterwards, two independent authors were involved in screening the results from the electronic databases by title, abstract, and 
Table I Eligibility Criteria

\begin{tabular}{|c|c|}
\hline Inclusion Criteria & Exclusion Criteria \\
\hline 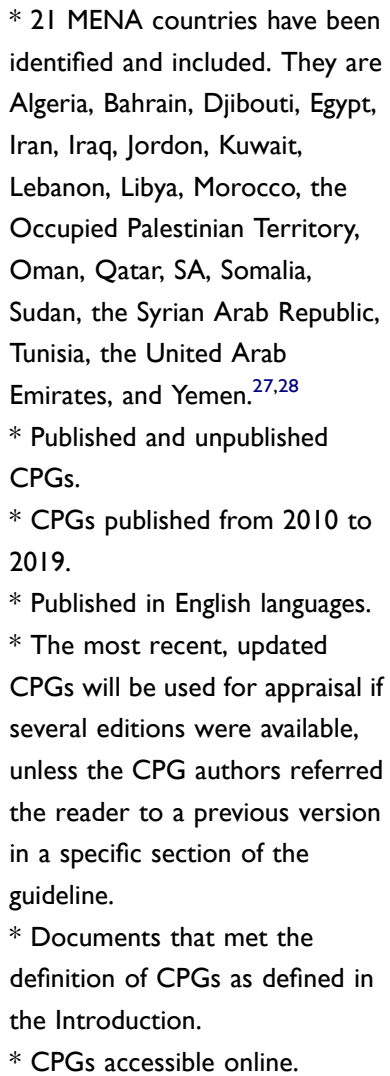 & $\begin{array}{l}\text { * Languages apart from English. } \\
\text { * Separate recommendation } \\
\text { papers regarding the treatment } \\
\text { only (short summaries) or } \\
\text { papers dedicated for patients. } \\
\text { * Guidelines developed especially } \\
\text { for HCPs other than doctors } \\
\text { and/or clinical pharmacists (eg, } \\
\text { physiotherapists and nurses). } \\
\text { * Guidelines used for a single } \\
\text { institution (eg, guidelines } \\
\text { regarding infection control) or in } \\
\text { a specific hospital. } \\
\text { * Adopted guidelines. } \\
\text { * Non-disease oriented, that is, } \\
\text { guidelines on specific } \\
\text { instructions in using certain } \\
\text { medications. }\end{array}$ \\
\hline
\end{tabular}

then full text to select eligible guidelines. Conflicts and disagreements were resolved by discussion or by the involvement of an independent reviewer, if necessary. Also, two authors independently extracted and assessed the quality of the selected CPGs. Extracted data included the CPG name, specialty, year of publication, and country.

\section{AGREE II Instrument Domain Descriptions}

The AGREE II Instrument consists of six major domains that include a total of 23 different items. ${ }^{10}$ The domains includes, scope and purpose, stakeholder involvement, rigor of development, clarity of presentation, applicability and editorial independence. Following these domains, there are two general rating items also known as overall assessments. The first overall assessment question requires the user to make a judgment regarding the overall quality of a guideline, taking into consideration the criteria considered in the assessment process. In the second overall assessment question, the user is asked whether she/he recommends using the $\mathrm{CPG}$ or not. ${ }^{10}$
Each of the 23 items of the six domains and the overall assessment questions were rated as a part of the quality assessment. The AGREE II Instrument provides a rating scale from 1 to 7 with 1 indicating strong disagreement and 7 indicating strong agreement. The points between 2 and 6 can be chosen depending on the quality of reporting and its completeness. After rating the items, the score of each domain should be calculated independently. This is done by the summation of each item's score in the domain and then calculating the total by scaling the domain's score as percentage of the maximum possible score. The formula for calculating the scaled score is as follows:

Obtained score - Minimum possible score/Maximum possible score - Minimum possible score.

No specific score is defined as a minimum score by the AGREE II consortium. Thus, determining whether a CPG is of high or low quality is the decision of the user of the instrument. Consequently, for this review, a quality score threshold was selected considering all six domain scores to be $60 \%$ and above based on consensus among the authors. Therefore, high-quality guidelines will be those in which all domains score $60 \%$ or more. ${ }^{10}$

\section{Data Synthesis}

We used descriptive statistics with mean (SD), median, and range for each domain score, calculated using Microsoft Excel $(2016) .^{30}$

\section{Results \\ Selection of CPGs}

Following the authors' systematic search strategy, a total of 346 records were identified in the previously described databases, with an additional 19 papers identified through the gray literature search. After removing duplicates, the number of guidelines was 314, of which 235 were found to be irrelevant after screening by title and abstract, and 6 were excluded as duplicates. Therefore, 73 guidelines were considered for full-text screening, and 12 of these were excluded for different reasons mentioned in the flow chart (Figure 1). The final number of included guidelines was 61 .

\section{Clinical Practice Guidelines Characteristics}

The description of the general characteristics of the assessed guidelines including the date and origin is illustrated in 


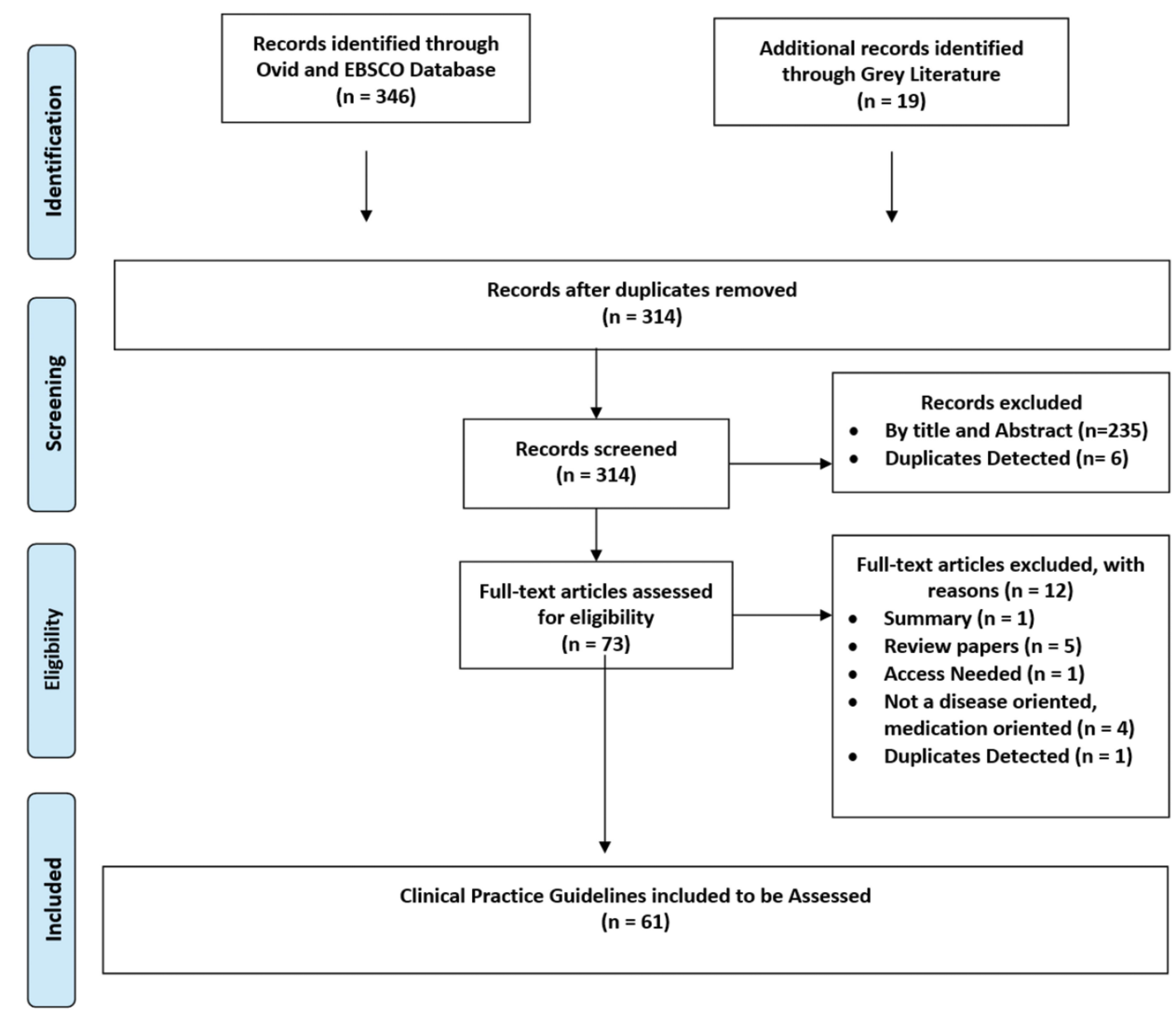

Figure I Flow diagram of the selection process of CPGs.

(Table 2). Among the 61 selected CPGs, 34 guidelines were from Saudi Arabia, ${ }^{31-64} 12$ were from multiple MENA countries, ${ }^{65-76}$ eight were from Lebanon, ${ }^{77-84}$ three were from Bahrain, ${ }^{85-87}$ and one was from each of the following countries: Iran, ${ }^{88}$ Egypt, ${ }^{89}$ and Jordan. ${ }^{90}$

\section{AGREE II Appraisal Results}

The main domains that had higher scores were clarity of presentation (mean $82 \%$, range $39-100 \%$ ) and scope and purpose (mean 63\%, range 3-100\%); meanwhile, domains with the lowest scores were rigor of development (mean 28\%, range 0-71\%), applicability (mean $29 \%$, range $0-75 \%$ ), stakeholders' involvement (mean $53 \%$, range $14-97 \%$ ), and editorial independence (mean $59 \%$, range $0-100 \%$ ).

Out of the 61 guidelines, $58(95 \%)$ guidelines scored $>60 \%$ in the clarity of presentation domain, whereas only $5(8 \%)$ and $7(11.5 \%)$ scored $>60 \%$ in applicability and rigor of development, respectively. The summary statistics for CPG quality assessment are presented in Table 3. The detailed assessment is presented in Appendix 3.

\section{Discussion}

This study was performed to examine the quality of CPGs in the MENA region using the AGREE II Instrument. In this review, a total of 61 guidelines were suitable for inclusion, and their quality varied. Among the six domains of the AGREE II Instrument, CPGs scored the highest on clarity of presentation (mean $82 \%$ ), while the lowest score was granted to the rigor of development domain (mean 28\%).

Our results were consistent with those of similar reviews assessing CPGs in Turkey, Sri Lanka, and China. ${ }^{7-9}$ The similarities were that the lowest scores were attributed to the rigor of development and applicability domains, whereas the highest scores were attained in the clarity of presentation followed by the scope and purpose domain. As opposed to the findings of $\mathrm{Hu}$ et $\mathrm{al}^{9}$, editorial independence, which includes the role of funding bodies and potential conflicts of interest, was sufficiently reported in $50 \%$ of the included guidelines. This indicates the transparency of the guideline development process in the MENA region.

The impact of economic status on clinical practice and research has been widely investigated. ${ }^{91-93}$ Few systematic 
Table 2 Characteristics of CPGs

\begin{tabular}{|c|c|c|c|c|}
\hline CPG ID & CPG Title & Specialty & Year & Country \\
\hline Haddad et al ${ }^{107}$ & $\begin{array}{l}\text { The } 2018 \text { Lebanese Society of Infectious Diseases and Clinical } \\
\text { Microbiology Guidelines for the use of antimicrobial therapy in } \\
\text { complicated intra-abdominal infections in the era of } \\
\text { antimicrobial resistance. }\end{array}$ & $\begin{array}{l}\text { Infectious } \\
\text { disease }\end{array}$ & 2019 & Lebanon \\
\hline Jazieh et $\mathrm{al}^{31}$ & Saudi lung cancer prevention and screening guidelines. & Oncology & 2018 & SA \\
\hline Al Amro et $\mathrm{al}^{32}$ & $\begin{array}{l}\text { Practical guidelines for screening and treatment of retinopathy } \\
\text { of prematurity in Saudi Arabia. }\end{array}$ & Ophthalmology & 2018 & SA \\
\hline Abusamra et al ${ }^{43}$ & The Saudi Clinical Management guidelines for prostate cancer. & Oncology & 2018 & SA \\
\hline Alharbi et al ${ }^{54}$ & $\begin{array}{l}\text { The Saudi Clinical Management Guidelines for Urothelial Cell } \\
\text { Carcinoma of the Urinary Bladder }\end{array}$ & Oncology & 2018 & SA \\
\hline Bazarbashi et al ${ }^{109}$ & $\begin{array}{l}\text { The Saudi Clinical Management guidelines for renal cell } \\
\text { carcinoma }\end{array}$ & Oncology & 2018 & SA \\
\hline Husni et $\mathrm{al}^{77}$ & $\begin{array}{l}\text { The Lebanese society of infectious diseases and clinical } \\
\text { microbiology guidelines for the treatment of urinary tract } \\
\text { infections. }\end{array}$ & $\begin{array}{l}\text { Infectious } \\
\text { disease }\end{array}$ & 2017 & Lebanon \\
\hline Jazieh et $\mathrm{a}^{60}$ & Saudi lung cancer management guidelines 2017. & Oncology & 2017 & SA \\
\hline Al-Hameed et $\mathrm{al}^{61}$ & $\begin{array}{l}\text { The Saudi clinical practice guideline for the prophylaxis of } \\
\text { venous thromboembolism in long-distance travelers. }\end{array}$ & Hematology & 2017 & SA \\
\hline Al-Jahdali et $\mathrm{al}^{62}$ & $\begin{array}{l}\text { The Saudi Thoracic Society guidelines for diagnosis and } \\
\text { management of noncystic fibrosis bronchiectasis. }\end{array}$ & $\begin{array}{l}\text { Respiratory } \\
\text { disorders }\end{array}$ & 2017 & SA \\
\hline Bashiri et al ${ }^{63}$ & $\begin{array}{l}\text { Management of convulsive status epilepticus in children: An } \\
\text { adapted clinical practice guideline for pediatricians in Saudi Arabia. }\end{array}$ & Neurology & 2017 & SA \\
\hline Al-Jazairi et $\mathrm{al}^{64}$ & $\begin{array}{l}\text { Guidelines for the secondary prevention of rheumatic heart } \\
\text { disease: Endorsed by Saudi Pediatric Infectious Diseases } \\
\text { Society (SPIDS). }\end{array}$ & Rheumatology & 2017 & SA \\
\hline Al-Hameed et $\mathrm{al}^{33}$ & $\begin{array}{l}\text { The Saudi clinical practice guideline for the prophylaxis of } \\
\text { venous thromboembolism in medical and critically ill patients. }\end{array}$ & Hematology & 2016 & SA \\
\hline Alfadda et $\mathrm{a}^{34}$ & $\begin{array}{l}\text { The Saudi clinical practice guideline for the management of } \\
\text { overweight and obesity in adults }\end{array}$ & $\begin{array}{l}\text { Metabolic } \\
\text { disorders }\end{array}$ & 2016 & SA \\
\hline Alotaibi et $\mathrm{al}^{35}$ & $\begin{array}{l}\text { Saudi Oncology Society and Saudi Urology Association } \\
\text { combined clinical management guidelines for testicular germ } \\
\text { cell tumors. }\end{array}$ & Oncology & 2016 & SA \\
\hline Alfadhel et $\mathrm{al}^{75}$ & $\begin{array}{l}\text { Guidelines for acute management of hyperammonemia in the } \\
\text { Middle East region. }\end{array}$ & $\begin{array}{l}\text { Acid Base } \\
\text { disorders }\end{array}$ & 2016 & ME \\
\hline Al-Moamary et $\mathrm{al}^{36}$ & $\begin{array}{l}\text { The Saudi Initiative for Asthma-2016 update: Guidelines for the } \\
\text { diagnosis and management of asthma in adults and children. }\end{array}$ & $\begin{array}{l}\text { Respiratory } \\
\text { disorders }\end{array}$ & 2016 & SA \\
\hline Al-Salam et $\mathrm{al}^{37}$ & $\begin{array}{l}\text { The golden hour approach: Practical guidelines of the Saudi } \\
\text { neonatology society on managing very low birth weight infants } \\
\text { in the first hour of life. }\end{array}$ & Neonatology & 2016 & SA \\
\hline Al-Mandeel et $\mathrm{al}^{38}$ & $\begin{array}{l}\text { Clinical practice guidelines on the screening and treatment of } \\
\text { precancerous lesions for cervical cancer prevention in Saudi Arabia. }\end{array}$ & Oncology & 2014 & SA \\
\hline
\end{tabular}

(Continued) 
Table 2 (Continued).

\begin{tabular}{|c|c|c|c|c|}
\hline CPG ID & CPG Title & Specialty & Year & Country \\
\hline Alavian et $\left.\mathrm{a}\right|^{87}$ & $\begin{array}{l}\text { Recommendations for the clinical management of hepatitis } C \text { in } \\
\text { Iran: A consensus-based national guideline. }\end{array}$ & Hepatology & 2016 & Iran \\
\hline Alsanea et $\mathrm{al}^{39}$ & $\begin{array}{l}\text { National Guidelines for Colorectal Cancer Screening in Saudi } \\
\text { Arabia with strength of recommendations and quality of evidence. }\end{array}$ & Oncology & 2015 & SA \\
\hline Al-Hameed et al ${ }^{40}$ & $\begin{array}{l}\text { Prophylaxis and treatment of venous thromboembolism in } \\
\text { patients with cancer: The Saudi clinical practice guideline. }\end{array}$ & Hematology & 2015 & SA \\
\hline Al-Hameed et $\mathrm{al}^{4 \mathrm{I}}$ & $\begin{array}{l}\text { The Saudi clinical practice guideline for the diagnosis of the } \\
\text { first deep venous thrombosis of the lower extremity. }\end{array}$ & Hematology & 2015 & SA \\
\hline Al-Saleh et $\mathrm{al}^{42}$ & $\begin{array}{l}2015 \text { guidelines for osteoporosis in Saudi Arabia: } \\
\text { Recommendations from the Saudi Osteoporosis Society. }\end{array}$ & Endocrinology & 2015 & SA \\
\hline Al-Hameed et $\mathrm{al}^{44}$ & $\begin{array}{l}\text { The Saudi clinical practice guideline for the treatment of venous } \\
\text { thromboembolism: Outpatient versus inpatient management. }\end{array}$ & Hematology & 2015 & SA \\
\hline Alothman et $\mathrm{al}^{74}$ & $\begin{array}{l}\text { Clinical practice guidelines for the management of invasive } \\
\text { Candida infections in adults in the Middle East region: Expert } \\
\text { panel recommendations. }\end{array}$ & $\begin{array}{l}\text { Infectious } \\
\text { diseases }\end{array}$ & 2014 & ME \\
\hline Ibrahim et $\mathrm{al}^{88}$ & $\begin{array}{l}\text { The Egyptian Hypertension Society: Egyptian hypertension } \\
\text { guidelines. }\end{array}$ & Cardiology & 2014 & Egypt \\
\hline Khan e al ${ }^{45}$ & $\begin{array}{l}\text { Saudi Guidelines on the Diagnosis and Treatment of Pulmonary } \\
\text { Hypertension: Pregnancy in pulmonary hypertension. }\end{array}$ & Pulmonology & 2014 & SA \\
\hline Khan et $\mathrm{al}^{47}$ & The Saudi guidelines for the diagnosis and management of COPD. & $\begin{array}{l}\text { Respiratory } \\
\text { disorders }\end{array}$ & 2014 & SA \\
\hline Al-Abdely et $\mathrm{al}^{73}$ & $\begin{array}{l}\text { Clinical practice guidelines for the treatment of invasive } \\
\text { Aspergillus infections in adults in the Middle East region: Expert } \\
\text { panel recommendations. }\end{array}$ & $\begin{array}{l}\text { Infectious } \\
\text { diseases }\end{array}$ & 2014 & ME \\
\hline Moghnieh et al ${ }^{78}$ & $\begin{array}{l}\text { The Lebanese Society for Infectious Diseases and Clinical } \\
\text { Microbiology (LSIDCM) guidelines for adult Community- } \\
\text { Acquired Pneumonia (CAP) in Lebanon. }\end{array}$ & $\begin{array}{l}\text { Infectious } \\
\text { diseases }\end{array}$ & 2014 & Lebanon \\
\hline Idrees et $\mathrm{al}^{46}$ & $\begin{array}{l}\text { Saudi guidelines on the diagnosis and treatment of pulmonary } \\
\text { hypertension: } 2014 \text { updates. }\end{array}$ & $\begin{array}{l}\text { Pulmonary } \\
\text { hypertension }\end{array}$ & 2014 & SA \\
\hline Abdo et $\mathrm{al}^{48}$ & $\begin{array}{l}\text { Saudi guidelines for the diagnosis and management of hepatocellular } \\
\text { carcinoma: Technical review and practice guidelines. }\end{array}$ & Oncology & 2012 & SA \\
\hline Al Jahdali et al ${ }^{49}$ & $\begin{array}{l}\text { Saudi guidelines for testing and treatment of latent tuberculosis } \\
\text { infection. }\end{array}$ & $\begin{array}{l}\text { Infectious } \\
\text { diseases }\end{array}$ & 2010 & SA \\
\hline Bohlega et $\mathrm{al}^{72}$ & $\begin{array}{l}\text { Guidelines for the pharmacological treatment of peripheral } \\
\text { neuropathic pain: Expert panel recommendations for the } \\
\text { middle east region. }\end{array}$ & Neurology & 2010 & ME \\
\hline Okasha et al ${ }^{67}$ & $\begin{array}{l}\text { Arab treatment guidelines for the management of major } \\
\text { depressive disorder. }\end{array}$ & Psychiatry & 2017 & Arab \\
\hline Shatila et $\mathrm{al}^{79}$ & LSN MS guidelines for the management of multiple sclerosis. & Neurology & 2012 & Lebanon \\
\hline Jassim et $a^{68}$ & $\begin{array}{l}\text { Pan Arab Osteoporosis Society Guidelines for Osteoporosis } \\
\text { Management }\end{array}$ & Endocrinology & 2017 & Arab \\
\hline
\end{tabular}

(Continued) 
Table 2 (Continued).

\begin{tabular}{|c|c|c|c|c|}
\hline CPG ID & CPG Title & Specialty & Year & Country \\
\hline $\begin{array}{l}\text { Jordanian Osteoporosis Prevention } \\
\text { Society }{ }^{89}\end{array}$ & Jordanian Osteoporosis Prevention Society Guideline-20I7 & Endocrinology & 2017 & Jordan \\
\hline $\begin{array}{l}\text { EBHC guidelines on Venous } \\
\text { Thromboembolism in Patients with } \\
\text { Stroke }^{51}\end{array}$ & $\begin{array}{l}\text { Clinical Practice Guideline on Prevention of Venous } \\
\text { Thromboembolism in Patients with Stroke }\end{array}$ & Hematology & 2014 & SA \\
\hline $\begin{array}{l}\text { EBHC guideline on Allergic Rhinitis in } \\
\text { Asthma }^{52}\end{array}$ & Clinical Practice Guideline on Allergic Rhinitis in Asthma & $\begin{array}{l}\text { Ear, Nose and } \\
\text { Throat }\end{array}$ & 2014 & SA \\
\hline $\begin{array}{l}\text { EBHC guideline on the Diagnosis of First } \\
\text { Deep Vein Thrombosis of Lower } \\
\text { Extremity }{ }^{10}\end{array}$ & $\begin{array}{l}\text { Clinical Practice Guideline on the Diagnosis of Suspected First } \\
\text { Deep Vein Thrombosis of Lower Extremity }\end{array}$ & Hematology & 2014 & SA \\
\hline $\begin{array}{l}\text { EBHC guideline on the Use of } \\
\text { Thrombolytic Therapy in Acute Stroke }{ }^{53}\end{array}$ & $\begin{array}{l}\text { Clinical Practice Guideline on the Use of Thrombolytic } \\
\text { Therapy in Acute Stroke }\end{array}$ & Neurology & 2014 & SA \\
\hline $\begin{array}{l}\text { EBHC guideline on Fracture Prevention } \\
\text { in Elderly }{ }^{55}\end{array}$ & $\begin{array}{l}\text { Clinical Practice Guideline on the Role of Vitamin D, Calcium } \\
\text { and Exercise in Fracture Prevention in Elderly }\end{array}$ & Endocrinology & 2014 & SA \\
\hline $\begin{array}{l}\text { EBHC guideline on Antithrombotic } \\
\text { Treatment of Patients with Non-valvular } \\
\text { Atrial Fibrillation }^{56}\end{array}$ & $\begin{array}{l}\text { Clinical Practice Guideline on Antithrombotic Treatment of } \\
\text { Patients with Non-valvular Atrial Fibrillation }\end{array}$ & Cardiology & 2014 & SA \\
\hline $\begin{array}{l}\text { EBHC guideline on the Treatment of } \\
\text { Venous Thromboembolism }\end{array}$ & $\begin{array}{l}\text { Clinical Practice Guideline on the Treatment of Venous } \\
\text { Thromboembolism }\end{array}$ & Hematology & 2014 & SA \\
\hline $\begin{array}{l}\text { EBHC guideline on Screening Strategies } \\
\text { for the Detection of Breast Cancer }\end{array}$ & $\begin{array}{l}\text { Clinical Practice Guideline on the Use of Screening Strategies } \\
\text { for the Detection of Breast Cancer }\end{array}$ & Oncology & 2014 & SA \\
\hline Alhasan et $\mathrm{a}^{50}$ & $\begin{array}{l}\text { Clinical Practice Guideline on the Timing of Initiation of } \\
\text { Dialysis }\end{array}$ & Nephrology & 2015 & SA \\
\hline $\begin{array}{l}\text { Bahrain } \mathrm{MOH} \text { guidelines on Middle East } \\
\text { Respiratory Syndrome coronavirus }{ }^{84}\end{array}$ & $\begin{array}{l}\text { Guideline On Middle East Respiratory Syndrome coronavirus } \\
\text { (MERS-CoV) }\end{array}$ & $\begin{array}{l}\text { Infectious } \\
\text { diseases }\end{array}$ & 2014 & Bahrain \\
\hline $\begin{array}{l}\text { Bahrain } \mathrm{MOH} \text { guidelines for } \\
\text { Management of Suspected or Confirmed } \\
\text { Cholera }^{85}\end{array}$ & Guideline for Management of Suspected or Confirmed Cholera & $\begin{array}{l}\text { Infectious } \\
\text { diseases }\end{array}$ & 2015 & Bahrain \\
\hline $\begin{array}{l}\text { Bahrain } \mathrm{MOH} \text { guidelines for } \\
\text { Management of Influenza } \mathrm{A}(\mathrm{HINI})^{86}\end{array}$ & $\begin{array}{l}\text { Management of Influenza } A(\mathrm{HINI}) \text { and Influenza like Illness } \\
\text { (ILI) }\end{array}$ & $\begin{array}{l}\text { Infectious } \\
\text { diseases }\end{array}$ & 2015 & Bahrain \\
\hline $\begin{array}{l}\text { Lebanese Ministry of public health } \\
\text { guidelines for Tuberculosis Prevention, } \\
\text { Care }^{80}\end{array}$ & $\begin{array}{l}\text { National Guidelines for Tuberculosis Prevention, Care and } \\
\text { Elimination in LEBANON- } 2017\end{array}$ & $\begin{array}{l}\text { Infectious } \\
\text { diseases }\end{array}$ & 2017 & Lebanon \\
\hline Ziadé et $\mathrm{al}^{81}$ & $\begin{array}{l}\text { Protocol for prescription and follow up of biologics and } \\
\text { targeted Synthetic Disease Modifying AntiRheumatic Drugs (b/ } \\
\text { tsDMARDS) in the management of Chronic Inflammatory } \\
\text { Rheumatic Diseases (CIRDs): Rheumatoid Arthritis (RA), Axial } \\
\text { Spondylo Arthritis (AxSpa), Psoriatic Arthritis (PsA) }\end{array}$ & Rheumatology & 2018 & Lebanon \\
\hline Mokhbat et $\mathrm{al}^{82}$ & $\begin{array}{l}\text { National Guidelines for diagnosis and management of HIV } \\
\text { infected adults. ANTIRETROVIRAL THERAPY MANAGEMENT }\end{array}$ & HIV infection & 2012 & Lebanon \\
\hline Fuleihan et $\mathrm{al}^{83}$ & $\begin{array}{l}\text { (Osteoporosis Assessment and Treatment) FRAX Based } \\
\text { Lebanese Osteoporosis Guidelines } 2013\end{array}$ & Osteoporosis & 2013 & Lebanon \\
\hline
\end{tabular}

(Continued) 
Table 2 (Continued).

\begin{tabular}{|c|c|c|c|c|}
\hline CPG ID & CPG Title & Specialty & Year & Country \\
\hline Abulkhair et al ${ }^{65}$ & $\begin{array}{l}\text { Modification and implementation of NCCN guidelines on } \\
\text { breast cancer in the Middle East and North Africa region. }\end{array}$ & Oncology & 2010 & MENA \\
\hline Yusuf et $\mathrm{al}^{71}$ & $\begin{array}{l}\text { Modification and implementation of NCCN guidelines on } \\
\text { hepatobiliary cancers in the Middle East and North Africa region. }\end{array}$ & Oncology & 2010 & MENA \\
\hline Bazarbachi et al $^{66}$ & $\begin{array}{l}\text { Modification and implementation of NCCN guidelines on } \\
\text { lymphomas in the Middle East and North Africa region. }\end{array}$ & Oncology & 2010 & MENA \\
\hline Hassen et $\mathrm{al}^{70}$ & $\begin{array}{l}\text { Modification and implementation of NCCN guidelines on } \\
\text { prostate cancer in the Middle East and North Africa region. }\end{array}$ & Oncology & 2010 & MENA \\
\hline İçli et al ${ }^{69}$ & $\begin{array}{l}\text { Modification and implementation of NCCN guidelines on } \\
\text { colon cancer in the Middle East and North Africa region. }\end{array}$ & Oncology & 2010 & MENA \\
\hline Jazieh et $\mathrm{al}^{76}$ & $\begin{array}{l}\text { Modification and implementation of NCCN guidelines on non- } \\
\text { small cell lung cancer in the Middle East and North Africa region. }\end{array}$ & Oncology & 2010 & MENA \\
\hline
\end{tabular}

Abbreviations: EBHC, Evidence-Based Health Care; SA, Saudi Arabia; ME, Middle East; MOH, Ministry of Health; MENA, Middle East and North Africa.

Table 3 Summary of the Domain Scores of CPGs Using the AGREE II Instrument $(N=6 I)$

\begin{tabular}{|l|l|l|l|l|l|}
\hline \multirow{2}{*}{ Domains } & \multicolumn{2}{|l|}{ Clinical Practice Guidelines (n=6I) } & \multirow{2}{*}{ Domain Score >60\% No. (\%) } \\
\cline { 2 - 6 } & Mean & Median & SD & Range & \\
\hline Scope and purpose & $63 \%$ & $61 \%$ & $22.62 \%$ & $3-100$ & $37(60.6 \%)$ \\
Stakeholder involvement & $53 \%$ & $53 \%$ & $23.06 \%$ & $14-97$ & $20(32.7 \%)$ \\
Rigor of development & $28 \%$ & $20 \%$ & $21.44 \%$ & $0-71$ & $7(11.5 \%)$ \\
Clarity of Presentation & $82 \%$ & $83 \%$ & $15.20 \%$ & $39-100$ & $58(95 \%)$ \\
Applicability & $29 \%$ & $23 \%$ & $19.37 \%$ & $0-75$ & $5(8 \%)$ \\
Editorial independence & $59 \%$ & $63 \%$ & $40.60 \%$ & $0-100$ & $32(52.5 \%)$ \\
\hline
\end{tabular}

reviews have been conducted to compare and identify the gaps in several guidelines in low-income and middleincome countries compared with high-income countries. ${ }^{94-96}$ Since some of the MENA countries are classified as low-income and middle-income, as described in the data of the World Bank, the results of such research can be taken into consideration. ${ }^{28}$ Results from those reviews found several factors in the CPGs of low- and middle-income countries that had an impact on their quality and resulted in less clear and applicable guidelines. ${ }^{28,95}$ These factors can be broadly classified into evidencerelated and contextual-related. ${ }^{97,98}$ Regarding evidencerelated factors, the ability to search and critique clinical evidence is limited in developing countries. ${ }^{97,98}$ Moreover, Baradaran-Seyed et al state that despite the awareness of health-research priorities and needs, using existing knowledge from daily practice to inform larger clinical studies is suboptimal. ${ }^{97}$ Additionally, Owolabi et al found that there is a lack of compliance with the trustworthiness standards as defined in the Institute of medicine for guideline development. ${ }^{95}$ One of the quality assessment items within the rigor of development domain was procedure for updating. ${ }^{10}$ Some reviews showed that most of these guidelines were outdated, older than 5 years, which is an issue since medical knowledge is evolving and many updates occur regularly. ${ }^{28,95}$

Contextual-related factors mainly affect the applicability of guidelines. ${ }^{10}$ Healthcare policies and economic and contextual factors vary among different countries of the MENA region. ${ }^{99}$ For example, the access and efficient utilization of primary healthcare services in the region is suboptimal. ${ }^{100}$ In addition, despite the global reduction of communicable disease and the increasing rate of noncommunicable diseases, some countries in the MENA region, such as Egypt and Morocco, have an increasing trend for both types. ${ }^{99}$ Workforce in the region is a major 
concern, and the number of physicians per 1000 people is lower than expected for middle-income countries such as Yemen, Morocco, the West Bank and Gaza, and Iraq. This factor is also superimposed with a lack of training and professional development, especially in rural regions. ${ }^{101}$ Finally, out-of-pocket expenditures account for $74 \%$ of private health expenditures, a factor that negatively affects the disadvantaged population. This may explain the reasons behind the poor quality of CPGs in the MENA region, especially in the development and applicability domains.

\section{Strengths and Limitations}

To the authors' knowledge, this is the first review performed on the assessment of the quality of CPGs in the MENA region. The search for clinical practice guidelines extends beyond medical journals, and this breadth enhances the inclusiveness of the search strategy.

A major limitation in this study is that our search strategy excludes non-English language studies, and this exclusion may result in language and publication bias. Moreover, poorly indexed studies and those not indexed in PubMed, EMBASE, databases might be missed. In addition, the included clinical practice guidelines have several weaknesses in their design and reporting that may limit the conclusions of this systematic review. The quality assessment of guidelines was assessed by two appraisers, according to the AGREE II guidance, the preferred number of appraisers is four which increases the reliability.

Finally, we could not access the hard copies published by governmental bodies and ministries of health, this could limit the comprehensiveness of grey literature search.

\section{Implications}

Identifying weaknesses and areas for improvement in CPGs of the MENA region can guide policymakers and organizations, such as the ministries of health, to implement several strategies to develop high-quality CPGs.

First, a guideline development group should consist of a multidisciplinary team including clinicians, epidemiologists and statisticians, policymakers, and patients' advocates. These members need to receive special training in the development process for guidelines, which includes but is not limited to effective searching in medical databases, critical appraisal, and utilization of The Grading of
Recommendations Assessment, Development, and Evaluation (GRADE tool). ${ }^{102}$

In addition, the strengthening of collaboration between clinicians, researchers, professional societies, and stakeholders in the MENA region is urgently needed. ${ }^{103}$ This can be achieved by inviting clinicians and researchers to join guideline development groups, thereby creating a healthy environment where local and international experts meet and share their experience. The involvement of patients and the general public is important in the guideline development phase as it enhances the shared decision-making process and thus improves patient outcomes. ${ }^{104,105}$ Despite the importance of such involvement, studies have reported suboptimal engagement. Therefore, effective utilization of patient support groups and health charity associations as a potential source for targeted patients is warranted. Tackling these issues could potentially enhance the quality of local guidelines and thus increase their implementation and potential impact.

\section{Conclusion}

From this review, it was found that the number of retrieved guidelines published in the MENA region is limited considering the large geographical area of the MENA region. The main domains with higher quality scores were clarity of presentation and scope and purpose, whereas domains with the lowest scores were rigor of development and applicability. The authors' findings will help policymakers identify areas for improvement in CPGs, and this identification can lead them to implement strategies such as the training of individuals and the recruitment of international experts to ultimately develop high-quality CPGs.

\section{Disclosure}

The authors report no conflicts of interest for this work.

\section{References}

1. Institute of Medicine. Clinical practice guidelines we can trust [Internet]. Washington, DC: The National Academies Press; 2011. Available from: https://www.nap.edu/catalog/13058/clinical-practiceguidelines-we-can-trust. Accessed December 29, 2020.

2. McCormack JP, Loewen P. Adding "value" to clinical practice guidelines. Can Fam Physician. 2007;53(8):1326-1327.

3. Kredo T, Bernhardsson S, Machingaidze S, et al. Guide to clinical practice guidelines: the current state of play. Int $J$ Qual Heal Care. 2016;28(1):122-128. doi:10.1093/intqhe/mzv115

4. Pincus D, Kuhn JE, Sheth U, et al. A systematic review and appraisal of clinical practice guidelines for musculoskeletal soft tissue injuries and conditions. Am J Sports Med. 2017;45(6):1458-1464. doi:10.1177/ 0363546516667903 
5. Woolf SH, Grol R, Hutchinson A, Eccles M, Grimshaw J. Potential benefits, limitations, and harms of clinical guidelines. BMJ. 1999;318(7182):527-530. doi:10.1136/bmj.318.7182.527

6. Alonso-Coello P, Irfan A, Solà I, et al. The quality of clinical practice guidelines over the last two decades: a systematic review of guideline appraisal studies. Qual Saf Heal Care. 2010;19(6):e58.

7. Yaşar I, Kahveci R, Baydar Artantaş A, et al. Quality assessment of clinical practice guidelines developed by professional societies in Turkey. PLoS One. 2016;11(6):e0156483. doi:10.1371/journal. pone. 0156483

8. Talagala IA, Samarakoon Y, Senanayake S, Abeysena C. Sri Lankan clinical practice guidelines: a methodological quality assessment utilizing the AGREE II instrument. $J$ Eval Clin Pract. 2019;25(4):630-636. doi:10.1111/jep.13048

9. $\mathrm{Hu} \mathrm{J}$, Chen $\mathrm{R}, \mathrm{Wu} \mathrm{S}$, et al. The quality of clinical practice guidelines in China: a systematic assessment. $J$ Eval Clin Pract. 2013;19(5):961-967. doi:10.1111/j.1365-2753.2012.01893.x

10. Brouwers MC, Kho ME, Browman GP, et al. AGREE II: advancing guideline development, reporting and evaluation in health care. Cmaj. 2010;182(18):E839-42. doi:10.1503/cmaj.090449

11. Shallwani SM, King J, Thomas R, et al. Methodological quality of clinical practice guidelines with physical activity recommendations for people diagnosed with cancer: a systematic critical appraisal using the AGREE II tool. PLoS One. 2019;14(4): e0214846. doi:10.1371/journal.pone. 0214846

12. Hou XF, Li M, He W, et al. Quality assessment of kidney cancer clinical practice guidelines using AGREE II instrument: a critical review. Med (United States). 2019;98(40):e17132.

13. Bragge P, Guy S, Boulet M, Ghafoori E, Goodwin D, Wright B. A systematic review of the content and quality of clinical practice guidelines for management of the neurogenic bladder following spinal cord injury. Spinal Cord. 2019;57(7):540-549. doi:10. 1038/s41393-019-0278-0

14. Bhatt M, Nahari A, Wang P-W, et al. The quality of clinical practice guidelines for management of pediatric type 2 diabetes mellitus: a systematic review using the AGREE II instrument. Syst Rev. 2018;7(1):193. doi:10.1186/s13643-018-0843-1

15. Hayawi LM, Graham ID, Tugwell P, Abdelrazeq SY, Williams BO. Screening for osteoporosis: a systematic assessment of the quality and content of clinical practice guidelines, using the AGREE II instrument and the IOM standards for trustworthy guidelines. PLoS One. 2018;13(12):e0208251. doi:10.1371/journal.pone.0208251

16. Wang $\mathrm{Y}, \mathrm{Li} \mathrm{H}$, Wei H, et al. Assessment of the quality and content of clinical practice guidelines for post-stroke rehabilitation of aphasia. Medicine (Baltimore). 2019;98(31):e16629. doi:10.10 97/MD.0000000000016629

17. Barth JH, Misra S, Aakre KM, et al. Why are clinical practice guidelines not followed? Clin Chem Lab Med. 2015;54(7):1133-1139.

18. Brouwers MC, Florez ID, McNair SA, Vella ET, Yao X. Clinical practice guidelines: tools to support high quality patient care. Semin Nucl Med. 2019;49(2):145-152. doi:10.1053/j.semnuclmed.2018.11.001

19. Eady EA, Layton AM, Sprakel J, Arents BWM, Fedorowicz Z, van Zuuren EJ. AGREE II assessments of recent acne treatment guidelines: how well do they reveal trustworthiness as defined by the U.S. Institute of Medicine criteria? Br J Dermatol. 2017;177 (6):1716-1725. doi:10.1111/bjd.15777

20. Duarte-García A, Cavalcante M, Arabelovic S, Wong JB. Systematic appraisal of the American College of Rheumatology Clinical Practice Guidelines. ACR Open Rheumatol. 2019;1 (3):188-193. doi:10.1002/acr2.1027

21. Nelson AE, Allen KD, Golightly YM, Goode AP, Jordan JM. A systematic review of recommendations and guidelines for the management of osteoarthritis: the chronic osteoarthritis management initiative of the U.S. Bone and Joint Initiative. Semin Arthritis Rheum. 2014;43(6):701-712. doi:10.1016/j.semarthrit.2013.11.012
22. Werner RN, Marinovic B, Rosumeck S, et al. The quality of European dermatological guidelines: critical appraisal of the quality of EDF guidelines using the AGREE II instrument. $J$ Eur Acad Dermatol Venereol. 2016;30(3):395-403. doi:10.1111/jdv.13358

23. Jarl G, Hellstrand Tang U, Nordén E, Johannesson A, Rusaw DF. Nordic clinical guidelines for orthotic treatment of osteoarthritis of the knee: a systematic review using the AGREE II instrument. Prosthet Orthot Int. 2019;43(5):556-563. doi:10.1177/03093646 19857854

24. Gamst-Jensen H, Vedel PN, Lindberg-Larsen VO, Egerod I. Acute pain management in burn patients: appraisal and thematic analysis of four clinical guidelines. Burns. 2014;40 (8):1463-1469. doi:10.1016/j.burns.2014.08.020

25. Ou Y, Goldberg I, Migdal C, Lee PP. A critical appraisal and comparison of the quality and recommendations of glaucoma clinical practice guidelines. Ophthalmology. 2011;118(6):10 17-1023. doi:10.1016/j.ophtha.2011.03.038

26. Eldin C, Raffetin A, Bouiller K, et al. Review of European and American guidelines for the diagnosis of Lyme borreliosis. Med Mal Infect. 2019;49(2):121-132. doi:10.1016/j.medmal.2018. 11.011

27. The World Bank. Middle East and North Africa [Internet]; 2020. Available from: https:/www.worldbank.org/en/region/mena. Accessed December 29, 2020.

28. World Bank Country and Lending Groups; 2020. Available from: https://datahelpdesk.worldbank.org/knowledgebase/articles/906519world-bank-country-and-lending-groups. Accessed December 29, 2020.

29. Jabbour S. Public health in the Arab World: at a crossroads. J Public Health Policy. 2013;34(2):356-360. doi:10.1057/jphp. 2013.2

30. Microsoft Corporation. Microsoft excel [Internet]; 2020. Available from: https://www.microsoft.com/ar-ww/microsoft365? $\mathrm{rtc}=1$. Accessed December 29, 2020.

31. Jazieh A, Alghamdi M, Alghanem S, et al. Saudi lung cancer prevention and screening guidelines. Ann Thorac Med. 2018;13 (4):198-204. doi:10.4103/atm.ATM_147_18

32. Al Amro SA, Al Aql F, Al Hajar S, et al. Practical guidelines for screening and treatment of retinopathy of prematurity in Saudi Arabia. Saudi J Ophthalmol. 2018;32(3):222-226. doi:10.1016/j. sjopt.2018.07.007

33. Al-Hameed FM, Al-Dorzi HM, Abdelaal MA, et al. The Saudi clinical practice guideline for the prophylaxis of venous thromboembolism in medical and critically ill patients. Saudi Med J. 2016;37(11):1279. doi:10.15537/smj.2016.11.15268

34. Alfadda AA, Al-Dhwayan MM, Alharbi AA, et al. The Saudi clinical practice guideline for the management of overweight and obesity in adults. Saudi Med J. 2016;37(10):1151. doi:10.15537/ smj.2016.10.14353

35. Alotaibi M, Saadeddin A, Bazarbashi S, et al. Saudi Oncology Society and Saudi Urology Association combined clinical management guidelines for testicular germ cell tumors. Urol Ann. 2016;8(2).

36. Al-Moamary MS, Alhaider SA, Idrees MM, et al. The Saudi Initiative for Asthma-2016 update: guidelines for the diagnosis and management of asthma in adults and children. Ann Thorac Med. 2016;11(1):3. doi:10.4103/1817-1737.173196

37. Al-Salam Z, Al-Alaiyan S, Alallah J, et al. The golden hour approach: practical guidelines of the Saudi neonatology society on managing very low birth weight infants in the first hour of life. J Clin Neonatol. 2016;5(4):222. doi:10.4103/22494847.194178

38. Al-Mandeel HM, Sagr E, Sait K, et al. Clinical practice guidelines on the screening and treatment of precancerous lesions for cervical cancer prevention in Saudi Arabia. Ann Saudi Med. 2016;36 (5):313-320. doi:10.5144/0256-4947.2016.313 
39. Alsanea N, Almadi MA, Abduljabbar AS, et al. National guidelines for colorectal cancer screening in Saudi Arabia with strength of recommendations and quality of evidence: tripartite task force from Saudi Society of Colon \& Rectal Surgery, Saudi Gastroenterology Association and Saudi Oncology Society. Ann Saudi Med. 2015;35(3):189-195. doi:10.5144/0256-4947.2015.189

40. Al-Hameed F, Al-Dorzi HM, Al Momen A, et al. Prophylaxis and treatment of venous thromboembolism in patients with cancer: the Saudi clinical practice guideline. Ann Saudi Med. 2015;35 (2):95-106. doi:10.5144/0256-4947.2015.95

41. Al-Hameed F, Al-Dorzi HM, Shamy A, et al. The Saudi clinical practice guideline for the diagnosis of the first deep venous thrombosis of the lower extremity. Ann Thorac Med. 2015;10 (1):3. doi:10.4103/1817-1737.146849

42. Al-Saleh Y, Sulimani R, Sabico S, et al. 2015 guidelines for osteoporosis in Saudi Arabia: recommendations from the Saudi Osteoporosis Society. Ann Saudi Med. 2015;35(1):1-12. doi:10.5144/0256-4947.2015.1

43. Abusamra A, Murshid E, Kushi H, et al. Saudi oncology society and Saudi urology association combined clinical management guidelines for prostate cancer. Urol Ann. 2016;10(2):138-145.

44. Al-Hameed FM, Al-Dorzi HM, Al-Momen AM, et al. The Saudi Clinical Practice Guideline for the treatment of venous thromboembolism: outpatient versus inpatient management. Saudi Med J. 2015;36(8):1004. doi:10.15537/smj.2015.8.12024

45. Khan J, Idrees MM. Saudi guidelines on the diagnosis and treatment of pulmonary hypertension: pregnancy in pulmonary hypertension. Ann Thorac Med. 2014;9(Suppl 5):S108. doi:10.4103/1817-1737.134050

46. Idrees MM, Saleemi S, Azem MA, et al. Saudi guidelines on the diagnosis and treatment of pulmonary hypertension: 2014 updates. Ann Thorac Med. 2014;9(Suppl 1):S1. doi:10.4103/ 1817-1737.134006

47. Khan JH, Lababidi HMS, Al-Moamary MS, et al. The Saudi guidelines for the diagnosis and management of COPD. Ann Thorac Med. 2014;9(2):55. doi:10.4103/1817-1737.128843

48. Abdo AA, Hassanain M, AlJumah A, et al. Saudi guidelines for the diagnosis and management of hepatocellular carcinoma: technical review and practice guidelines: created and endorsed by the Saudi Association for the Study of Liver Diseases and Transplantation and the Saudi Oncology Society. Ann Saudi Med. 2012;32(2):174-199. doi:10.5144/0256-4947.2012.174

49. Al Jahdali HH, Baharoon S, Abba AA, et al. Saudi guidelines for testing and treatment of latent tuberculosis infection. Ann Saudi Med. 2010;30(1):38-49. doi:10.4103/0256-4947.59373

50. The Saudi Center for Evidence Based Health Care. Clinical practice guideline on the timing of initiation of dialysis. 2015.

51. The Saudi Center for Evidence Based Health Care. Clinical practice guideline on prevention of venous thromboembolism in patients with stroke. 2014.

52. The Saudi Center for Evidence Based Health Care. Clinical practice guideline on allergic rhinitis in asthma. 2014.

53. The Saudi Center for Evidence Based Health Care. Clinical practice guideline on the use of thrombolytic therapy in acute stroke. 2014.

54. Alharbi H, Alkhateeb S, Murshid E, et al. Saudi Oncology Society and Saudi Urology Association combined clinical management guidelines for urothelial cell carcinoma of the urinary bladder 2017. Urol Ann. 2018;10(2):133. doi:10.4103/UA.UA_176_17

55. The Saudi Center for Evidence Based Health Care. Clinical practice guideline on the role of vitamin D, calcium and exercise in fracture prevention in elderly. 2014.

56. The Saudi Center for Evidence Based Health Care. Clinical practice guideline on antithrombotic treatment of patients with non-valvular atrial fibrillation. 2014.
57. The Saudi Center for Evidence Based Health Care. Clinical practice guideline on the treatment of venous thromboembolism. 2014.

58. The Saudi Center for Evidence Based Health Care. Clinical practice guideline on the use of screening strategies for the detection of breast cancer. 2014.

59. Alsharm A, Bazarbashi S, Alghamdi A, et al. Saudi Oncology Society and Saudi Urology Association combined clinical management guidelines for renal cell carcinoma 2017. Urol Ann. 2018;10(2):123. doi:10.4103/UA.UA_175_17

60. Jazieh AR, Al Kattan K, Bamousa A, et al. Saudi lung cancer management guidelines 2017. Ann Thorac Med. 2017;12(4):221. doi:10.4103/atm.ATM_92_17

61. Al-Hameed FM, Al-Dorzi HM, Abdelaal MA, et al. The saudi clinical practice guideline for the prophylaxis of venous thromboembolism in long-distance travelers. Saudi Med J. 2017;38 (1):101-107. doi:10.15537/smj.2017.1.15738

62. Al-Jahdali H, Alshimemeri A, Mobeireek A, et al. The Saudi Thoracic Society guidelines for diagnosis and management of noncystic fibrosis bronchiectasis. Ann Thorac Med. 2017;12 (3):135. doi:10.4103/atm.ATM_171_17

63. Bashiri FA, Hamad MH, Amer YS, et al. Management of convulsive status epilepticus in children: an adapted clinical practice guideline for pediatricians in Saudi Arabia. Neurosciences. 2017;22(2):146. doi:10.17712/nsj.2017.2.20170093

64. Al-Jazairi A, Al-Jaser R, Al-Halees Z, et al. Guidelines for the secondary prevention of rheumatic heart disease: endorsed by Saudi Pediatric Infectious Diseases Society (SPIDS). Int $J$ Pediatr Adolesc Med. 2017;4(1):47-50. doi:10.1016/j.ijpam.2017.02.002

65. Abulkhair O, Saghir N, Sedky L, et al. Modification and implementation of NCCN guidelines ${ }^{\mathrm{TM}}$ on breast cancer in the Middle East and North Africa region. J Natl Compr Cancer Netw. 2010;8(Suppl_3):S-8.

66. Bazarbachi A, Azim HA, Alizadeh H, et al. Modification and implementation of NCCN guidelines ${ }^{\mathrm{TM}}$ on lymphomas in the Middle East and North Africa Region. J Natl Compr Cancer Netw. 2010;8(Suppl_3):S-29.

67. Okasha A, Alkhadhari S, Al Sharqi A, et al. Arab treatment guidelines for the management of major depressive disorder. Arab J Psychiatry. 2017;44(5487):1-21.

68. Jassim NA, Adib G, Rahman YAA, et al. Pan Arab Osteoporosis Society guidelines for osteoporosis management. Mediterr J Rheumatol. 2017;28(1):27.

69. İçli F, Akbulut H, Bazarbashi S, et al. Modification and implementation of NCCN guidelines ${ }^{\mathrm{TM}}$ on colon cancer in the Middle East and North Africa Region. J Natl Compr Cancer Netw. 2010;8(Suppl_3):S-22.

70. Hassen WA, Karsan FA, Abbas F, et al. Modification and implementation of NCCN guidelines ${ }^{\mathrm{TM}}$ on prostate cancer in the Middle East and North Africa Region. J Natl Compr Cancer Netw. 2010;8(Suppl_3):S-26.

71. Yusuf MA, Kapoor VK, Kamel RR, et al. Modification and implementation of NCCN guidelines ${ }^{\mathrm{TM}}$ on hepatobiliary cancers in the Middle East and North Africa Region. J Natl Compr Cancer Netw. 2010;8(Suppl_3):S-36.

72. Bohlega S, Alsaadi T, Amir A, et al. Guidelines for the pharmacological treatment of peripheral neuropathic pain: expert panel recommendations for the Middle East region. J Int Med Res. 2010;38(2):295-317. doi:10.1177/147323001003800201

73. Al-Abdely HM, Alothman AF, Al Salman J, et al. Clinical practice guidelines for the treatment of invasive Aspergillus infections in adults in the Middle East region: expert panel recommendations. J Infect Public Health. 2014;7(1):20-31. doi:10.1016/j.jiph.2013.08.003

74. Alothman AF, Al-Musawi T, Al-Abdely HM, et al. Clinical practice guidelines for the management of invasive Candida infections in adults in the Middle East region: expert panel recommendations. J Infect Public Health. 2014;7(1):6-19. doi:10.1016/j.jiph.2013.08.002 
75. Alfadhel M, Al Mutairi F, Makhseed N, et al. Guidelines for acute management of hyperammonemia in the Middle East region. Ther Clin Risk Manag. 2016;12:479. doi:10.2147/TCRM.S93144

76. Jazieh A-R, Bamefleh H, Demirkazik A, et al. Modification and implementation of NCCN guidelines ${ }^{\mathrm{TM}}$ on non-small cell lung cancer in the Middle East and North Africa Region. J Natl Compr Cancer Netw. 2010;8(Suppl_3):S-16.

77. Husni R, Atoui R, Choucair J, et al. The Lebanese Society of Infectious Diseases and Clinical Microbiology: guidelines for the treatment of urinary tract infections. Leban Med J. 2017;103 (5521):1-12.

78. Moghnieh R, Sakr NY, Kanj SS, Musharrafieh U, Husni R. The Lebanese Society for Infectious Diseases and Clinical Microbiology (LSIDCM) guidelines for adult community-acquired pneumonia (CAP) in Lebanon. Leban Med J. 2014;103(1006):1-8.

79. Shatila AR, Koussa S, Jabbour R, et al. LSN MS guidelines for the management of multiple sclerosis. Rev Neurol (Paris). 2013;169(12):950-955. doi:10.1016/j.neurol.2012.12.002

80. Ministry of public health. National guidelines for tuberculosis prevention, care and elimination in Lebanon. 2017.

81. Ziadé N, Menassa J, Saliba G, Baraliakos X, Ramiro S, Chatzidionysiou $\mathrm{K}$ Protocol for prescription and follow up of biologics and targeted synthetic disease modifying anti-rheumatic drugs (b/tsDMARDS) in the management of chronic inflammatory rheumatic diseases (RA, axSpA, PsA). 2018.

82. Mokhbat JE. National Guidelines for diagnosis and management of HIV infected adults. Antiretroviral Ther Manag. 2012.

83. Fuleihan GEH. FRAX based Lebanese osteoporosis guidelines [Internet]; 2013. Available from: https://www.moph.gov.lb/user files/files/Quality $\% 26 \mathrm{~S}$ afety/Osteoporosis Assessment $\%$ 26Treatment/FRAX-guidelines.pdf. Accessed December 29, 2020.

84. Ministry of Health Kingdom of Bahrain. Guideline on Middle East respiratory syndrome coronavirus (MERS-CoV). 2014.

85. Ministry of Health Kingdom of Bahrain. Guideline for management of suspected or confirmed cholera. 2015.

86. Ministry of Health Kingdom of Bahrain. Management of Influenza A (H1N1) and Influenza like Illness (ILI). 2015.

87. Alavian SM, Hajarizadeh B, Lankarani $\mathrm{KB}$, et al. Recommendations for the clinical management of hepatitis $\mathrm{C}$ in Iran: a consensus-based national guideline. Hepat Mon. 2016;16 (8). doi:10.5812/hepatmon.guideline.

88. Ibrahim MM. Egyptian hypertension guidelines. Egypt Heart J. 2014;66:79-132.

89. Jordanian Osteoporosis Prevention Society. The practical guide for management of osteoporosis. 2016.

90. Alemayehu C, Mitchell G, Nikles J. Barriers for conducting clinical trials in developing countries- a systematic review. Int $J$ Equity Health. 2018;17(1):37. doi:10.1186/s12939-018-0748-6

91. Mcmichael C, Waters E, Volmink J. Evidence-based public health: what does it offer developing countries? J Public Health (Oxf). 2005;27:215-221. doi:10.1093/pubmed/fdi024

92. Røttingen JA, Chamas C, Goyal LC, Harb H, Lagradae L, Mayosi BM. Securing the public good of health research and development for developing countries. Bull World Health Organ. 2012;90(5):398-400. doi:10.2471/BLT.12.105460

93. Owolabi M, Olowoyo P, Miranda J, et al. Gaps in hypertension guidelines in low- and middle-income versus high-income countries: a systematic review. Hypertension. 2016;68(6):1328-1337. doi:10.1161/HYPERTENSIONAHA.116.08290

94. Owolabi MO, Yaria JO, Daivadanam M, et al. Gaps in guidelines for the management of diabetes in low- and middle-income versus high-income countries - a systematic review. Diabetes Care. 2018;41(5):1097-1105. doi:10.2337/dc17-1795
95. Bayona H, Owolabi M, Feng W, et al. A systematic comparison of key features of ischemic stroke prevention guidelines in lowand middle-income vs. high-income countries. J Neurol Sci. 2017;375:360-366. doi:10.1016/j.jns.2017.02.040

96. Baradaran-Seyed Z, Nedjat S, Yazdizadeh B, Nedjat S, Majdzadeh R. Barriers of clinical practice guidelines development and implementation in developing countries: a case study in Iran. Int J Prev Med. 2013;4(3):340-348.

97. Dizon JM, Grimmer K, Louw Q, Machingaidze S, Parker H, Pillen H. Barriers and enablers for the development and implementation of allied health clinical practice guidelines in South African primary healthcare settings: a qualitative study. Heal Res Policy Syst. 2017;15(1):79. doi:10.1186/s12961-017-0243-3

98. Mate K, Bryan C, Deen N, McCall J. Review of health systems of the Middle East and North Africa Region. Int Encycl Public Health. 2017;347-356.

99. Fadlallah R, Bou-Karroum L, El-Jardali F, et al. Quality, safety and performance management in primary health care: from scoping review to research priority setting and implementation plan in the Eastern Mediterranean Region. BMJ Global Health. 2020;4: e001477. doi:10.1136/bmjgh-2019-001477

100. Pierre-Louis AM, Akala FA, Karam HS. Public Health in the Middle East and North Africa: Meeting the Challenges of the Twenty-First Century. World Bank; 2004.

101. GRADE HOME; 2020. Available from: https://www.gradewor kinggroup.org/. Accessed December 29, 2020.

102. El-Jardali F, Lavis JN, Ataya N, Jamal D. Use of health systems and policy research evidence in the health policymaking in eastern Mediterranean countries: views and practices of researchers. Implement Sci. 2012;7:2. doi:10.1186/1748-5908-7-2

103. Stacey D, Légaré F, Lewis K, et al. Decision aids for people facing health treatment or screening decisions. Cochrane Database Syst Rev. 2017;4(4):CD001431. doi:10.1002/146518 58.CD001431.pub5

104. Hack TF, Degner LF, Watson P, Sinha L. Do patients benefit from participating in medical decision making? Longitudinal follow-up of women with breast cancer. Psychooncology. 2006;15(1):9-19. doi:10.1002/pon.907

105. Boivin A, Légaré F, Gagnon MP. Competing norms: Canadian rural family physicians' perceptions of clinical practice guidelines and shared decision-making. J Heal Serv Res Policy. 2008;13 (2):79-84. doi:10.1258/jhsrp.2007.007052

106. Schünemann HJ, Fretheim A, Oxman AD. Improving the use of research evidence in guideline development 10 . Integrating values and consumer involvement. Heal Res Policy Syst. 2006;5(4):22. doi:10.1186/1478-4505-4-22

107. Haddad N, Kanj SS, Awad LS, Abdallah DI, Moghnieh RA. The 2018 Lebanese Society of Infectious Diseases and Clinical Microbiology Guidelines for the use of antimicrobial therapy in complicated intra-abdominal infections in the era of antimicrobial resistance. BMC Infect Dis. 2019;19(1):293. doi:10.1186/s12879019-3829-2

108. World Bank Country and Lending Groups [Internet]; 2020. Available from: https://datahelpdesk.worldbank.org/knowledge base/articles/906519-world-bank-country-and-lending-groups. Accessed December 29, 2020.

109. Bazarbashi S, Alkhateeb S, Abusamra A, et al. Saudi Oncology Society and Saudi Urology Association combined clinical management guidelines for renal cell carcinoma. Urol Ann. 2014;6 (4):286. doi:10.4103/0974-7796.140974

110. Saudi Ministry of Health $(\mathrm{MOH})$. Clinical practice guideline on the diagnosis of suspected first deep vein thrombosis of lower extremity: Saudi Center for Evidence based Healthcare. 2014. 


\section{Publish your work in this journal}

The Journal of Multidisciplinary Healthcare is an international, peerreviewed open-access journal that aims to represent and publish research in healthcare areas delivered by practitioners of different disciplines. This includes studies and reviews conducted by multidisciplinary teams as well as research which evaluates the results or conduct of such teams or healthcare processes in general. The journal

covers a very wide range of areas and welcomes submissions from practitioners at all levels, from all over the world. The manuscript management system is completely online and includes a very quick and fair peer-review system. Visit http://www.dovepress.com/testimonials. php to read real quotes from published authors. 